\begin{tabular}{|c|c|c|}
\hline \multicolumn{2}{|r|}{ JSM (10) (2) } & \\
\hline (2) & JURNAL SENI MUSIK & \\
\hline & https://journal.unnes.ac.id/sju/index.php/jsm/index & \\
\hline
\end{tabular}

\title{
Creating An E-Module For A Basic Musical Instrument \\ (Compulsory Piano Course)
}

\author{
Lingga Ramafisela ${ }^{\bowtie 1}$ \\ Departement of Music Education, ISI Yogyakarta, Indonesia
}

\begin{tabular}{|c|c|}
\hline Article Info & Abstract \\
\hline $\begin{array}{l}\text { Keywords: } \\
\text { design, e-modul, basic } \\
\text { instrument, compulsary } \\
\text { piano }\end{array}$ & $\begin{array}{l}\text { Learning basic instruments (compulsory piano) is a basic piano practice course that must be } \\
\text { taken for all students except for piano major students. Learning this basic instrument (compulsory } \\
\text { piano) encountered obstacles, namely that students still did not understand and could play the } \\
\text { piano. This is certainly an obstacle in the process of learning basic instruments (compulsory piano) } \\
\text { especially in the current situation where learning is carried out online. Electronic modules or e- } \\
\text { modules are needed to assist students in an effective and efficient learning process. This basic } \\
\text { instrument e-module design (compulsory piano) can function as a problem-solving idea, namely to } \\
\text { develop effective and efficient learning materials. The purpose of this study is to facilitate the } \\
\text { learning process in the basic instrument class (compulsory piano). The basic instrument e-module } \\
\text { design (compulsory piano) is an important element in online learning which is arranged in a } \\
\text { systematic and interesting way. This electronic module can be accessed using gadgets owned by } \\
\text { students and supports the environmentally friendly (paperless) movement. The research method } \\
\text { used is Research and Development with several stages, namely need assessment, design, and } \\
\text { development/implementation. The last stage in this research is evaluation and drawing } \\
\text { conclusions. The data are directly obtained in the basic instrument class (compulsory piano) in the } \\
\text { Music Education Study Program. This e-module design is expected to be useful for the effective and } \\
\text { efficient progress of the learning process for basic instruments (compulsory piano) in the Music } \\
\text { Education Study Program, FSP ISI Yogyakarta. }\end{array}$ \\
\hline
\end{tabular}




\section{INTRODUCTION}

A basic musical instrument or compulsory piano is a compulsory course in the undergraduate program of Music Education Study Program, ISI Yogyakarta. The compulsory piano course requires the students to practice piano and must be accomplished by all students except those who learn major instruments/piano principles, as well as being a prerequisite subject to take the manual harmony course that learns about chord progressions and accompaniment. The compulsory piano course also requires the students to be able to play the piano with reference to the predetermined standards so that, at least, the students can contribute to social life. Piano practice must be supported by the students' ability to read sheet music for piano, but in reality, they are often not fluent in reading scores and playing them on the piano despite the music knowledge they have received. It would be even worse if the students cannot read musical notation at all.

One of the challenges in the current circumstance is the online learning system which has an impact on teaching-learning activities. During the compulsory piano course, students must demonstrate their ability to play the piano with the use of video conference applications or by submitting video recordings. The difficulty experienced by students from various high school backgrounds is not being able to absorb the learning material explained by the lecturer and not being able to play the piano as exemplified. After the course, many students ask many questions about how to play the piano. This happens because of the constraint on the learning media and learning system which still cannot be conducted onsite so that a fast, precise, and practical solution is needed. Most of the students asked if there is a module whose language is easier to grasp. If this problem is left unsolved, this will become a protracted problem and hinder the essence of the compulsory piano course.

This research aims to create a systematic e-module to help students learn the material of the compulsory piano course. In the millennial era, the presence of electronic modules is highly necessary to support teaching and learning activities as they can be accessed easily using gadgets following current technological developments. The presence of e-modules is essential because students and lecturers can access them anywhere and anytime, thereby making both online and onsite learning processes more effective and efficient.

Module is a set of teaching material that is systematically arranged and packaged in its entirety containing learning objectives, learning materials, and evaluations to help students master specific learning objectives (Daryanto, 2013). Furthermore, module is a part of a learning unit designed in a planned manner to help students individually achieve their learning goals (Sukiman, 2012). Module is also a book that is compiled with the aim of assisting students to learn independently so that, at least, it is composed of the basic components of teaching materials that have been previously designed (Majid, 2016). Module has several features, namely: it is in the form of the smallest and complete teaching unit, contains a series of systematic learning activities, contains clear and specific learning objectives, and allows students to learn independently (Sudjana and Rivai, 2013).

In line with the module used by the Directorate General of Primary and Secondary Education, the Ministry of National Education in 2003, teaching materials have several characteristics, namely self-instructional, self-contained, stand-alone, adaptive, and user friendly (Lestari, 2013).

E-module is an electronic version of a learning module that can be accessed and used by electronic means (Depdiknas, 2008). E-modules are also commonly called autonomous learning media because they are equipped with instructions for self-study (Kuncahyono, 2018). E-module is a product development of print- and digital-based teaching materials which are independently designed to be explored by students (Sugihartini and Jayanta, 2017). Based on the aforementioned understanding, it is concluded that an e-module is a module in 
the digital form used by students to study autonomously as it has been equipped with comprehensible instructions following the learning design.

Creation according to the Big Indonesian Dictionary is an innovation, the way or act to create. In this case, creation is synonymous with innovation. Innovation or creation means a new idea or concept for a person or group of people who aims to solve certain problems (Kristiawan, 2018) (Rogers, 1983). This is in line with the definition of innovation according to Law Number 18 of 2002 which states that innovation is a research and development activity aiming to develop science.

The practice of piano scales has significant impacts on the improvement in students' basic technical skills, piano playing skills, and readiness to have piano performance (Demirci, 2012). The skills developed by individuals who will learn piano must include the development of basic piano playing techniques (Bulut \& Bulut, 2012). Playing the piano is a complex activity as it involves cognitive, psychomotor, and affective processing that requires high levels of concentration and skills (Kupana \& Otacioglu, 2012). One of the purposes of piano education is to introduce students to musical literacy and the basic techniques of piano (Uygun, 2012). Therefore, the presence of an emodule of the basic musical instrument is indispensable for the compulsory piano course.

\section{METHOD}

The research method of this research is R\&D (Research and Development). The R\&D method is used to create certain products and examine their effectiveness (Sugiyono, 2014). The research and development method in the education field is to design and produce learning products which are then systematically examined, evaluated, and refined into a learning product that meets the effectiveness, efficiency, and quality standards (Borg and Gall, 1983).

This study combines the R\&D method with the Hanafin and Peck development model/learning media design. The Hanafin and Peck model is a productoriented development model that consists of three phases: needs analysis, design, development and implementation (Hannafin, Michael J., and Peck, 1988). Each phase is elaborated as follows.

\section{Needs Analysis Phase}

Four stages must be fulfilled to conduct a needs analysis. These stages are planning, data collection, data analysis, and final report (Morrison et al., 2013).

1.1 Planning

Planning research locations and research samples. The research was conducted in the basic musical instrument class (compulsory piano course) of the undergraduate program of Music Education Study Program, FSP ISI Yogyakarta. The research sample was students who took the basic musical instrument class (compulsory piano course) and the lecturers who taught the course.

1.2 Data collection

Data was collected through library study, interviews and questionnaires, as well as field observations.

1.2.1 Library study was done by searching for literature related to the research topic. This literature search was carried out online and at the library of ISI Yogyakarta.

1.2.2 Interviews and questionnaires were addressed to students and lecturers who taught the basic musical instrument class (compulsory piano course) in the undergraduate program of Music Education Study Program.

1.2.3 Field observations were performed directly by the researcher who is also the lecturer of the basic musical instrument class (compulsory piano course) at the undergraduate program of Music Education Study Program, FSP ISI Yogyakarta. This was done to get the most out of online classes.

1.3 Data analysis

This phase was useful for making data analysis based on data collection that was in line with research needs.

1.4 Final report 
Final report contained the research objectives and methods that were used to create a product.

\section{Design Phase}

At this phase, the researcher has already known the design of the module to be developed. In the design phase, the needs analysis obtained in the first phase can be used as a reference for designing or creating an e-module. The researcher mapped out data collection techniques that were used to create e-modules and data analysis techniques to process the data gathered. The researcher developed the module designs that have been adjusted to the needs of lecturers and students and therefore can be useful for the learning process of the basic musical instrument (compulsory piano course) in the undergraduate program of Music Education Study Program, FSP ISI Yogyakarta.

\section{Development \\ Implementation Phase}

and

After creating the design of the emodule, the researcher created the emodule by considering the expectations of the course lecturers and student representatives. The researcher conducted FGDs with student representatives and course lecturers to examine the product/e-module for the basic musical instrument class (compulsory piano course) to attain satisfactory results.

Upon completion of all the phases, the researcher evaluated and drew conclusions by considering suggestions and input from students or lecturers who taught the basic musical instrument (compulsory piano course) in the undergraduate program of Music Education Study Program, FSP ISI Yogyakarta.

\section{RESULTS AND DISCUSSIONS}

The creation of the e-module for the basic musical instrument (compulsory piano course) is important for it is an innovation that is in accordance with the needs of lecturers and students. Creation according to the Big Indonesian Dictionary means an innovation, way or act to create (Setiawan, 2020). This is one of the products of the developments of science and technology in the social and cultural context. The e-module for the basic musical instrument (compulsory piano course) is expected to provide more convenience, effectiveness, and progress in the teaching and learning process in the undergraduate program of Music Education Study Program.

Based on the results of research on the e-module for the compulsory piano course that refers to the students' needs, the e-module was compiled with a variety of aspects of needs. This e-module for the basic musical instrument (compulsory piano course) possesses the same characteristics as the teaching materials, namely: selfinstructional, self-contained, stand-alone, adaptive, and user friendly (Lestari, 2013). First, self-instructional means the e-module encourages students to learn independently as it has clear objectives and learning materials that correspond to the material in the lesson plan. Second, self-contained means the e-module contains all competencies in a complete and systematic way. Third, stand-alone means that the emodule can stand alone and does not depend on other teaching materials. Fourth, adaptive means the e-module contains information that can increase readers' knowledge regarding the advancement of science and technology. Fifth, user-friendly means that every instruction and information display is helpful and easy to understand. The e-module aims to make readers easier to obtain information about the learning material.

This e-module contains the introduction of the piano instrument, the fundamentals of playing piano including sitting posture, body posture, and hand or finger position. This e-module also contains basic piano playing techniques, such as major and minor scales, three-note chord or triad, chords and cadences, etude sheet music, and songs that are usually played in the compulsory piano course. Scales are required to practice fingers and play piano with perfect pitch. Piano scale practice is 
started with playing one octave first, then extending it to two or more octaves. Scale is a collection of sequential notes and has a pitch according to the applicable rules. The scale exercise is a basic piano practice. This e-module uses attractive pictures to help students interpret more accurately every instruction in it. The following is the appearance and link of the e-module for the compulsory piano course: https://bit.ly/emodulpianowaiib

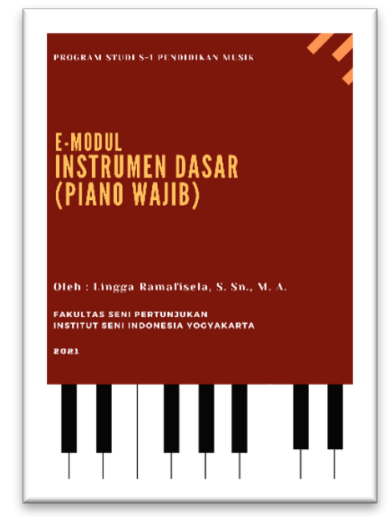

Figure 1. Screenshot of Cover E-Modul (Source : Ramafisela, 11 August 2021)
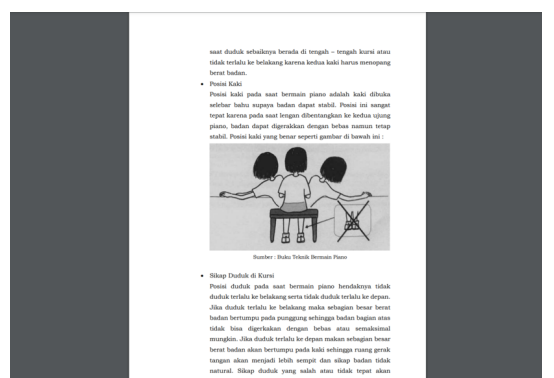

Figure 2. Screenshot of Introduction Foot Position on Piano

(Source : Ramafisela, 11 August 2021)

\section{CONCLUSION}

Based on the research results, it can be concluded that the E-Module for the Basic Musical Instrument (Compulsory Piano Course) is an innovation or invention that is systematically composed and aims to assist onsite and online learning. Students can always access the e- module using gadgets wherever they are. The instructions are reader-friendly and are easy to understand so that users or students can have the maximum opportunity to learn as much as possible. This research has overall been accomplished well and is able to achieve the predetermined research goal, namely creating an e-module of the basic musical instrument (compulsory piano course) in the undergraduate program of Music Education Study Program. It is expected that this e-module can continuously be utilized and the material will be updated to give a contribution to the world of education.

\section{REFERENCES}

Borg, W., \& Gall, M. (1983). Educational Research an Introduction fourth edition. Longman Inc.

Bulut, D., \& Bulut, F. (2012). The Problems of Piano Teachers in Fine Arts and Sports High Schools and the Solution Offers. Procedia - Social and Behavioral Sciences. https://doi.org/10.1016/j.sbspro.20 12.08.136

Daryanto. (2013). Menyusun Modul Bahan Ajar untuk Persiapan Guru dalam Mengajar. Yogyakarta: Gava Media (p. Yogyakarta Gava Media). Gava Media.

Demirci, S. A. (2012). Importance of Scales in Piano Education in Turkey. Procedia - Social and Behavioral Sciences. https://doi.org/10.1016/j.sbspro.20 12.05.444

Depdiknas. (2008). Panduan Pengembangan Bahan Ajar. Jakarta: Dirjen Manajemen Pendidikan Dasar dan Menengah.

Hannafin, Michael J. dan Peck, K. L. (1988). The Design, Development, and Evaluation of Instructional 
Software. New York: Macmillan.

Kristiawan, M., dkk. (2018). Inovasi Pendidikan. Ponorogo: WADE Group.

Kuncahyono. (2018). Pengembangan EModul dalam Pembelajaran Tematik Di Sekolah Dasar. JMIE (Journal of Madrasah Ibtidaiyah Education) 2(2), 2018, 219- 231.

Kupana, M. N., \& Otacioglu, S. G. (2012). Effect of the Teaching Piano Sight Reading Program Developed in Accordance with the Systematic Learning on the Sight Reading Skills of the Music Teacher Candidates. Procedia - Social and Behavioral Sciences.

https://doi.org/10.1016/j.sbspro.20 12.06.752

Lestari, I. (2013). Pengembangan Bahan Ajar Berbasis Kompetensi. Padang: Akademia Permata.

Majid, A. (2016). Strategi Pembelajaran. Bandung: Rosdakarya.

Morrison, G; Ross, S; Morrison, J; Kalman, H. (2013). Designing Effective Instruction. USA: John Wiley \& Sons, Inc.

Rogers, E. M. (1983). Rogers, E. M. 1983. Diffusion of Innovations. New York: The Free Press. New York: The Free Press.

Setiawan, E. (2020). rekacipta @ kbbi.web.id.

https://kbbi.web.id/rekacipta

Sudjana, N dan Rivai, A. (2013). Media Pengajaran. Bandung: Sinar Baru Algesindo.

Sugihartini, N., \& Jayanta, N. L. (2017). Pengembangan E-modul Mata kuliah Strategi Pembelajaran. Jurnal Pendidikan Teknologi Dan Kejuruan. https://doi.org/10.23887/jptk-

undiksha.v14i2.11830

Sugiyono. (2014). Metode Penelitian Pendidikan pendekatan Kuantitatif, Kualitatif dan R\&D. Bandung:Alfabeta.

Sukiman. (2012). Pengembangan Media Pembelajaran. Yogyakarta: Pedagogia.

Uygun, M. A. (2012). Scale for Determining Learning Approaches to Piano Lesson: Development, Validity and Reliability. Procedia Social and Behavioral Sciences. https://doi.org/10.1016/j.sbspro.20 12.08.263 